\title{
All in this together: the corporate capture of public health
}

The UK government is increasingly handing over its role of health policy maker to private corporations

\author{
Jennifer S Mindell clinical senior lecturer ${ }^{1}$, Lucy Reynolds research fellow ${ }^{2}$, David L Cohen consultant \\ physician $^{3}$, Martin McKee professor of European public health ${ }^{4}$
}

${ }^{1}$ Epidemiology and Public Health, University College London, London WC1E 6BT, UK; ${ }^{2}$ London School of Hygiene and Tropical Medicine, London WC1E 7HT, UK; ${ }^{3}$ Northwick Park Hospital, Harrow HA1 3UJ, UK; ${ }^{4}$ ECOHOST, London School of Hygiene and Tropical Medicine, London WC1E 7HT, UK

Society has changed fundamentally over the past 30 years. Citizens have become consumers with status proportional to purchasing power, and former public spaces have been enclosed and transformed into private malls for shopping as recreation or "therapy." Step by step, private companies, dedicated to enriching their owners, take over the core functions of the state. This process, which has profound implications for health policy, ${ }^{1}$ is promoted by politicians proclaiming an "ideology" of shrinking the state to the absolute minimum. These politicians envisage replacing almost all public service provision through outsourcing and other forms of privatisation such as "right to provide" management buyouts. ${ }^{2}$ This ambition extends far beyond health and social care, reaching even to policing and the armed forces.

Superficially, a case can be made for privatisation. Economic theorists argue that the creative energy of private companies will unlock innovation. Freed from state bureaucracy they will find new, clever ways of doing things better and cheaper. Yet the reality is often different. They appear more "efficient" than the public sector providers they replace, but they achieve this efficiency only by cutting wages or by failing to deliver what they promise. The list of failures grows daily, from the very public failure of the security services company G4S at the 2012 Olympics to the local problems of Serco's out of hours general practitioner service in Cornwall. ${ }^{3}$

So how is it that this new model, which often costs more (when all costs are considered) but delivers less, is allowed to persist? One obvious reason is political support. In part, this is ideological, but the ideology is encouraged and sustained by the temptations arising when politicians and senior civil servants know they will be offered safe and profitable retirement sinecures from which they can promote the interests of their new employers. All those involved, whether in government or companies, must convey the same message, lest they concede the inherent contradictions in their positions. While calling for a minimalist state in public, less visibly they encourage the role and the spending of the state to expand-whether in protecting their property interests (and increasingly what they claim as intellectual property), subsidising with benefits the low wages of their employees or bailing them out when things go wrong-because they have become "too big to fail." Yet the contradictions extend to the heart of the relationship between the state and business. The state is charged with advancing the welfare of its citizens; a company's purpose is to increase its owners' wealth, as enshrined in law (for example, the UK Companies Act, section 172). Crucially, despite claims made for corporate social responsibility and "public-private partnership," any duty on directors to "have regard to" their company's impact on the environment, society, and staff is subordinated to their obligation to maximise profits.

To maintain these contradictions, companies must write the rules of the game, aided by their collaborators in government. Remarkably, they are being allowed to do so. The following examples show the consequences of these contradictions for public health.

\section{Resisting regulation through "voluntary cooperation"}

Companies, understandably, seek a regulatory environment that allows them to thrive. As the basis for much regulation is to protect employees or the general public (whether from dangers at work, hazardous products, or mis-selling of financial products), a key goal for business is to shift responsibility from the company to the individual and then be seen rather as a partner in helping those individuals to make good choices than a threat to their health. The obesity epidemic is portrayed not 
as a consequence of aggressive marketing of cars and energy dense, nutrient poor food but rather as the idleness of gluttonous consumers who refuse to take enough exercise. ${ }^{4}$ By associating their brand images with sporting events such as the Olympics, companies such as Coca-Cola and McDonald's can portray themselves as part of the solution, not the problem. Smoking is presented as a matter of individual choice, totally divorced from the millions spent on promoting cigarettes in ways designed to attract, and promote addiction in, the next generation of smokers. The tobacco companies say they want to prevent young people from smoking, while funding youth antismoking campaigns in the full knowledge that by portraying smoking as "adult" they will actually increase initiation. ${ }^{5}$ In these ways, companies seek to control the health promotion agenda. However, this will happen only if companies maintain a veto over policy. And for this to happen, the regulatory regime must be voluntary rather than statutory. In this they have succeeded, even though there is now a wealth of evidence that voluntary agreements are generally ineffective. This is exemplified by the history of tobacco control in the United Kingdom: those voluntary measures advocated by the tobacco industry and supported by previous UK governments achieved little. ${ }^{6}$ As Daube has noted: "Manufacturers know better than anyone that tobacco control legislation is designed to succeed, but voluntary agreements are designed to fail, and in that they succeed brilliantly."

It took until 2007, over 40 years after the Royal College of Physicians published its seminal report on the dangers of smoking, ${ }^{8}$ to protect the non-smoking public by a ban on smoking in public places. ${ }^{9}$

\section{Resisting regulation on technical or economic grounds}

If governments do adopt legal regulations, it is important for companies to minimise the impact of these on profits. One argument they often use is that the proposed regulation will be either technically unfeasible or too expensive. The availability of "reduced ignition propensity" cigarettes (designed to extinguish themselves if not being actively smoked) is now mandatory throughout the European Union, despite the industry long arguing that it faced "insuperable technical difficulties," a position it maintained even after New York state had successfully issued a mandate for such cigarettes to be available. ${ }^{10}$ The food industry claimed that to ban food that contained trans fat would be too difficult and costly, ${ }^{11}{ }^{12}$ even though some European countries and US cities and states have shown it to be entirely feasible. ${ }^{13}$ The industry's claims often invoke the spectre of job losses, yet previous claims that pub, restaurant, tobacconist, and manufacturing jobs would be threatened by smoke-free legislation and bans on tobacco advertising have proved groundless. ${ }^{14}$ Indeed, the only studies seeming to show job losses are sponsored by the tobacco industry. ${ }^{15}$ Similar claims have been made for "traffic light" labelling on packaged food. ${ }^{16}$

\section{Subverting regulation by spreading disinformation}

Growing cynicism about certain industries has obliged these industries to find others to promulgate their messages. This involves "third party advocacy"- often by "independent" organisations that are fronted by "the public" or "independent experts," who advance pro-industry arguments. Increasingly industries are supported by manufactured "grass-roots" campaigning, now termed astroturfing. The organisation
FOREST (whose stated mission is "to protect the interests of adults who choose to smoke or consume tobacco" but which is funded principally by the tobacco industry), the National Federation of Retail Newsagents, and the Tobacco Retailers Alliance all campaign against smoke-free legislation and promotional bans using industry funding. The Taxpayers Alliance uses its substantial corporate funding to oppose tobacco control and support the interests of the oil and automobile industry. ${ }^{17}$ The neoliberal think tank Reform, which has actively propagated private sector involvement in the NHS, ${ }^{18}$ receives financial support from management consultancies benefiting from the NHS reforms $;{ }^{19}$ companies such as G4S and Serco (that is, companies to which public service organisations contract out their services), and the City of London Corporation. All these organisations would benefit greatly if Reform's vision of an NHS based on private health insurers and providers were realised. The interests of the drug industry are advanced by the patient groups that it supports and by doctors willing to promote its products. New guidance on collaboration between healthcare professionals and the pharmaceutical industry has been criticised for not stating adequately that it was coordinated and supported by the Association of the British Pharmaceutical Industry. ${ }^{20}$ Elsewhere, influence may be more subtle. The boards of the health policy think tanks - the King's Fund and the Nuffield Trust - include individuals from the City of London Corporation, management consultancies McKinsey and KPMG, and until recently the insurance company UnitedHealth.

Having created such vehicles, these industries then used them to communicate their corporate messages. Tactics refined by the tobacco industry have been adopted by, among others, food and alcohol producers seeking either to counter independent research findings or, more often, to sow confusion about their validity. These tactics are now well understood and have given rise to the term denialism. ${ }^{21}$ They include cherry-picking the evidence, moving the goal posts by setting impossible standards of proof, paying false experts, and promoting logical fallacies. Thus, studies funded by industry often reach systematically different conclusions from independent research ${ }^{22}{ }^{23}$ or suppress unfavourable findings. ${ }^{24}$ Studies on secondhand smoke undertaken by the cigarette industry were 88 times more likely than independent research to report it as harmless. ${ }^{25}$ For many years the tobacco industry argued erroneously that better ventilation was the solution to secondhand smoke rather than banning smoking in public places. ${ }^{26}$

The sums spent by industries in spreading their corporate messages are enormous. Car manufacturers report spending 2.5-3.5\% of their revenue on advertising, while spirits manufacturers allocate $5.5-7.5 \% .{ }^{27}$ However, this is only the start. Industry lavishes money on lobbyists and on entertaining policy makers. ${ }^{28}{ }^{29}$ The food industry spent $€ 1$ bn (£836m; \$1.4bn) on lobbying the EU against traffic light labelling on food. ${ }^{27}$ Tobacco industry lobbyists successfully influenced the adoption of an impact assessment procedure by the EU that emphasised economic impacts but paid scant attention to health impacts, thus benefiting their products. ${ }^{30}$ The drug industry spent $\$ 116 \mathrm{~m}$ on lobbying in the United States in $2011,{ }^{31}$ with $€ 40 \mathrm{~m}$ declared in the EU: there is reason to consider the second figure was a substantial underestimate. ${ }^{32}$

\section{Corporate "capture" of regulators}

If regulations are to be implemented, the industries they are regulating will, if at all possible, hijack or "capture" the regulatory process. Problems are inevitable where the regulators rely on those industries for their funding, something that has 
caused considerable concern in the US, where the Food and Drug Administration (FDA) receives much of its income from drug manufacturers. ${ }^{33}$ Concerns have also been voiced about the relationship between the pharmaceutical industry and the European Medicines Agency, which, Ben Goldacre has shown, has sometimes placed the interests of industry above public safety. ${ }^{34}$ The Chinese government was sufficiently concerned about covert industrial influence on pharmaceutical regulation that when the head of China's Food and Drug Administration was caught receiving bribes, he was executed-to enhance his colleagues' respect for the regulatory process. ${ }^{35}$

It is not just regulators with a direct interest in the product that must be captured. Large corporations have striven to relax regulatory controls on foreign direct investment in many low and middle income countries, thus facilitating the penetration of tobacco and junk foods and fuelling the global epidemic of non-communicable diseases. ${ }^{36}$

\section{Corporate capture of policy making}

The ultimate prize for industry is to determine government policy. It has achieved this in England with the Department of Health's "Public Health Responsibility Deal," in which committees dominated by industry agree programmes ostensibly intended to tackle the health problems arising from the products they manufacture or distribute. Some organisations, such as the Royal College of Physicians, have withdrawn from this discredited process, but others cling to the hope, against the evidence, that they might play a positive role.

Such examples, where industry influence on policy is brought into the open, are rare. More often it takes place behind closed doors. This is what is believed to have happened with the 2012 Health and Social Care Act, which promotes the commercial interests of the insurance, pharmaceutical, healthcare, and financial services industries. ${ }^{37}$ The Department of Health's draft Operating Framework for 2012-13 for the NHS in England even sets a target, PHF09, to raise the proportion of the NHS budget that funds non-public sector healthcare providers. The government's claims, disputed from the outset, that its legislation would support healthcare provision by charities and social enterprises, are now seen to be false as these smaller organisations cannot compete against the large corporations, many of which contribute generously to political coffers.

The centrality of US consultancy company McKinsey to the Department of Health's policy illustrates the interweaving of commercial agendas and health policy making: the Department of Health has hired McKinsey repeatedly since $1970,{ }^{29}$ enabling it to advertise inside knowledge to clients seeking to enter the emerging English healthcare industry. ${ }^{37}$ From around 2005 the Department of Health started wholesale outsourcing of health policy work, with McKinsey a main beneficiary, receiving $£ 9 \mathrm{~m}$ in 2009 alone. ${ }^{38}$ Since the coalition took power in 2010,

McKinsey has been paid at least $£ 13.8 \mathrm{~m}$ from the Department of Health's coffers ${ }^{37}$ and is now receiving $£ 250000$ a year to advise on the "transition" to a fully marketised NHS. ${ }^{39}$ It has also profited from the privatisation of hospital trusts: $£ 2 \mathrm{~m}$ to help on the current request for tenders to supply South London Healthcare NHS Trust's services ${ }^{40}$ and $£ 3 \mathrm{~m}$ to write a report that seeks to justify seeking tenders for the work of a London partnership of primary care trusts, NHS North West London. ${ }^{41}$

\section{Conclusion}

Evidence based health legislation is much more effective than voluntary agreements with industry, ${ }^{7}$ but it faces stiff opposition.
Recent disclosures about the "revolving door" between senior civil service posts, ministerial briefs, and corporate sinecures ${ }^{37}$ demonstrate wholesale commercial contamination of the making of health policy (box). As the World Health Organization has noted: "there are areas, such as public health policy-making and regulatory approval, where the concept of partnership with for-profit enterprise is not appropriate. ${ }^{, 42}$ It is inevitable that the resulting policies maximise benefit to shareholders rather than the public. Patient information, leading to informed choice, has been the government's mantra. Clinicians have more day to day contact with patients than do politicians. They traditionally keep away from politics in their consultations but have been vocal about policies that affect health, such as availability of tobacco and alcohol. Perhaps it is time to tell patients exactly how government and profit making businesses are affecting their health and healthcare. At the same time, it may be time for public health professionals to go back to their roots, consider all the determinants of health, and challenge the prevailing wisdom. ${ }^{43}$

Appointing the fox to guard the hen house by delegating policy making and regulation to commercial interests represents a dereliction of government responsibility that will inevitably raise suspicions of undue influence. $\Downarrow$

Contributors: JSM conceived and wrote the initial draft and is the guarantor. MMcK made major revisions after review. All authors contributed information from academic and professional commentaries on health related corporate activity and on the NHS reforms, helped amend earlier drafts, and approved the final draft.

Competing interests: All authors have completed the ICMJE uniform disclosure form at www.icmje.org/coi_disclosure.pdf (available on request from the corresponding author) and declare: no support from any organisation for the submitted work; no financial relationships with any organisations that might have an interest in the submitted work in the previous three years; no other relationships or activities that could appear to have influenced the submitted work.

Provenance and peer review: Commissioned; externally peer reviewed.

1 Hastings G. Why corporate power is a public health priority. BMJ 2012;345:e5124.

2 Letwin O. Privatising the world: a study of international privatisation in theory and practice. Cassell Educational, 1988.

3 Care Quality Commission. CQC publishes report on out of hours GP services in Cornwall. 2012. www.cqc.org.uk/media/cqc-publishes-report-out-hours-gp-services-cornwall.

4 Jenkin GL, Signal L, Thomson G. Framing obesity: the framing contest between industry and public health at the New Zealand inquiry into obesity. Obes Rev 2011:12:1022-30.

Landman A, Ling PM, Glantz SA. Tobacco industry youth smoking prevention programs: protecting the industry and hurting tobacco control. Am J Public Health 2002;92:917-30.

protecting the industry and hurting tobacco control. Am J Public Health 2002;92:917-30.
Mindell J. Lessons from tobacco control for advocates of healthy transport. J Public Health Med 2001;23(2):91-7.

Daube M. Voluntary agreements: designed to fail. Tob Control 1993;2:183-4.

8 Royal College of Physicians. Smoking and health. Royal College of Physicians, 1962.

9 Sims M, Maxwell R, Bauld L, Gilmore A. Short term impact of smoke-free legislation in England: retrospective analysis of hospital admissions for myocardial infarction. BMJ 2010;340:c2161.

10 O'Connor RJ, Giovino GA, Fix BV, Hyland A, Hammond D, Fong GT, et al. Smokers' reactions to reduced ignition propensity cigarettes. Tob Control 2006;15:45-9.

11 Eckel RH, Borra S, Lichtenstein AH, Yin-Piazza SY. Understanding the complexity of trans fatty acid reduction in the American diet. American Heart Association Trans Fat Conference 2006: report of the Trans Fat Conference Planning Group. Circulation 2007;115:2231-46.

12 Stender S, Dyerberg J, Bysted A, Leth T, Astrup A. A trans world journey. Atheroscler Suppl 2006;7(2):47-52.

13 Dwyer Hogg C. Dying for a burger? Why are trans fats still legal in the UK? Independent 10 September 2011. www.independent.co.uk/life-style/food-and-drink/features/dying-fora-burger-why-are-trans-fats-still-legal-in-the-uk-2351306.html

14 Quinn C, Lewis S, Edwards R, McNeill A. Economic evaluation of the removal of tobacco promotional displays in Ireland. Tob Control 2011;20:151-5.

15 Scollo M, Lal A, Hyland A, Glantz S. Review of the quality of studies on the economic effects of smoke-free policies on the hospitality industry. Tob Control 2003;12:13-20.

16 Leatherhead Food International. Evaluating the impact on business of changes to nutrition labelling requirements in the UK. Project undertaken for the Food Standards Agency. FSA, 2006.

17 Douglas MJ, Watkins SJ, Gorman DR, Higgins M. Are cars the new tobacco? J Public Health (Oxf) 2011;33:160-9.

18 Bosanquet N, Haldenby A, Hurley L, Jolly F, Rainbow H, Sikora K. Making the NHS the best insurance policy in the world. REFORM, 2008.

19 Cassidy J. Lobby watch: Reform. BMJ 2011;342:d2917. 


\section{Overseeing the revolving door}

Corporations can exert influence on ministers, civil servants, and special advisers while they are in post by holding out the possibility of employing them once they are no longer in post, and can benefit from their insider knowledge once they have stopped working for the employing them once they are no longer in post, and can benefit from their insider knowledge once they have stopped working for the
government. This highly unsatisfactory situation should be rectified by the code of conduct overseen by the Advisory Committee on Business Appointments, from which those in senior positions in government should seek advice if they take up any new appointment within two years. However, as described in detail by the House of Commons Public Administration Committee, ${ }^{44}$ this process is not working. The system is described as opaque and confusing, and its voluntary nature creates scope for abuse. The Public Administration Committee calls for a system of clear, statutory regulation, with enforceable penalties, overseen by an independent ethics commissioner with the power to initiate his or her own investigations, similar to the model in place in Canada.

\section{Key messages}

- Current public policy in the United Kingdom is dominated by an ideology of personal greed, leading to the transfer of public services to private corporations

- Corporate interests have subverted even a minimalist state role by, for example, promoting ineffective voluntary agreements; putting forward spurious technical or economic arguments; and marketing of disinformation

- The government has handed over its role of policy maker to the private sector through outsourcing deals funded by taxpayers

- These developments have profound and, so far, inadequately appreciated, implications for health

20 Rogers W, Zutlevics T, Raven M, Jureidini J. Guidance offers little in the way of ethics or transparency. BMJ 2012;344:e2910.

21 Diethelm P, McKee M. Denialism: what is it and how should scientists respond? Eur J Public Health 2009;19:2-4.

22 Bekelman JE, Li Y, Gross CP. Scope and impact of financial conflicts of interest in biomedical research: a systematic review. JAMA 2003;289:454-65.

23 Vartanian LR, Schwartz MB, Brownell KD. Effects of soft drink consumption on nutrition and health: a systematic review and meta-analysis. Am J Public Health 2007;97:667-75.

24 Gruning T, Gilmore AB, McKee M. Tobacco industry influence on science and scientists in Germany. Am J Public Health 2006:96:20-32.

25 Barnes DE, Bero LA. Why review articles on the health effects of passive smoking reach different conclusions. JAMA 1998;279:1566-70.

26 Drope J, Bialous SA, Glantz SA. Tobacco industry efforts to present ventilation as an alternative to smoke-free environments in North America. Tob Control 2004;13(supp 1):i41-7.

27 McKee S. What should you spend on advertising? Bloomberg Business Week 2009. www. businessweek.com/smallbiz/content/feb2009/sb20090210_165498.htm.

28 Brownell KD, Koplan JP. Front-of-package nutrition labeling - an abuse of trust by the food industry? N Engl J Med 2011;364:2373-5.

29 Leys C, Player S. The plot against the NHS. Merlin Press, 2011.

30 Smith KE, Fooks G, Collin J, Weishaar H, Mandal S, Gilmore AB. "Working the system"-British American tobacco's influence on the European union treaty and its implications for policy: an analysis of internal tobacco industry documents. PLOS Med 2010;7(1):e1000202.

31 Love J. Pharma company registered expenditures for USA. http://keionline.org/node/1321. Knowledge Economy International, 2011.

32 Health Action International. Europe/Corporate Europe Observatory. Divide and conquer: a look behind the scenes of the European Union (EU) pharmaceutical industry lobby. 2012. http://corporateeurope.org/sites/default/files/28\%20March\%202012\% 20DivideConquer.pdf.

33 Regulatory Affairs Associates. FDA corruption and the specter of regulatory capture. Regulatory Affairs Associates www.regaffairs.net/news/fda-corruption-the-specter-ofregulatory-capture.html.2009.

34 Goldacre B. Bad pharma. Fourth Estate, 2012
35 Kahn J. China quick to execute drug official. New York Times 11 July 2007. www.nytimes. com/2007/07/11/business/worldbusiness/11execute.html?_r=1\&pagewanted=all.

36 Stuckler D, McKee M, Ebrahim S, Basu S. Manufacturing epidemics: the role of global producers in increased consumption of unhealthy commodities including processed foods, alcohol, and tobacco. PLoS Med 2012;9(6):e1001235.

37 Rose D. The firm that hijacked the NHS. Mail on Sunday 12 February 2012:8-9. www. dailymail.co.uk/news/article-2099940/NHS-health-reforms-Extent-McKinsey--Companysrole-Andrew-Lansleys-proposals.html.

38 Jarman $\mathrm{H}$, Greer SL. In the eye of the storm: civil servants and managers in the UK Department of Health. Soc Pol Admin 2009:44:172-92.

39 Boffey D. NHS reforms: American consultancy McKinsey in conflict-of-interest row. Observer 5 November 2011. www.guardian.co.uk/society/2011/nov/05/nhs-reformsmckinsey-conflict-interest.

40 Department of Health. Invitation to tender for unsustainable providers regime (ITT number: 58529). Acceptance letter to McKinsey \& Co. dated 11th July 2012. http://library. constantcontact.com/download/get/file/1102665899193-1113/ SLHT+admin+Award+Letter+to+McKinsey+-+Redacted+Version.pdf.

41 MacFarlane J. NHS wastes £7million on 'sham' consultation over A\&E closures ... as we reveal six more casualty units to be cut. Daily Mail 28 October 2012. www.dailymail. co.uk/news/article-2224150/NHS-wastes-7million-sham-consultation-A-E-closures--revealSIX-casualty-units-cut.html\#ixzz2DL56It85.

42 World Health Organization. Trade, foreign policy, diplomacy and health. Public-private partnerships for health. 2012. www.who.int/trade/glossary/story077/en/index.html.

43 Lang T, Rayner G. Ecological public health: the 21st century's big idea? An essay by Tim Lang and Geof Rayner. BMJ 2012;345:e5466.

44 House of Commons Public Administration Committee. Third report. Business appointment rules. UK Parliament, 2012. www.publications.parliament.uk/pa/cm201213/cmselect/ cmpubadm/404/40402.htm.

Accepted: 14 November 2012

Cite this as: BMJ 2012;345:e8082

(c) BMJ Publishing Group Ltd 2012 


\section{Figure}

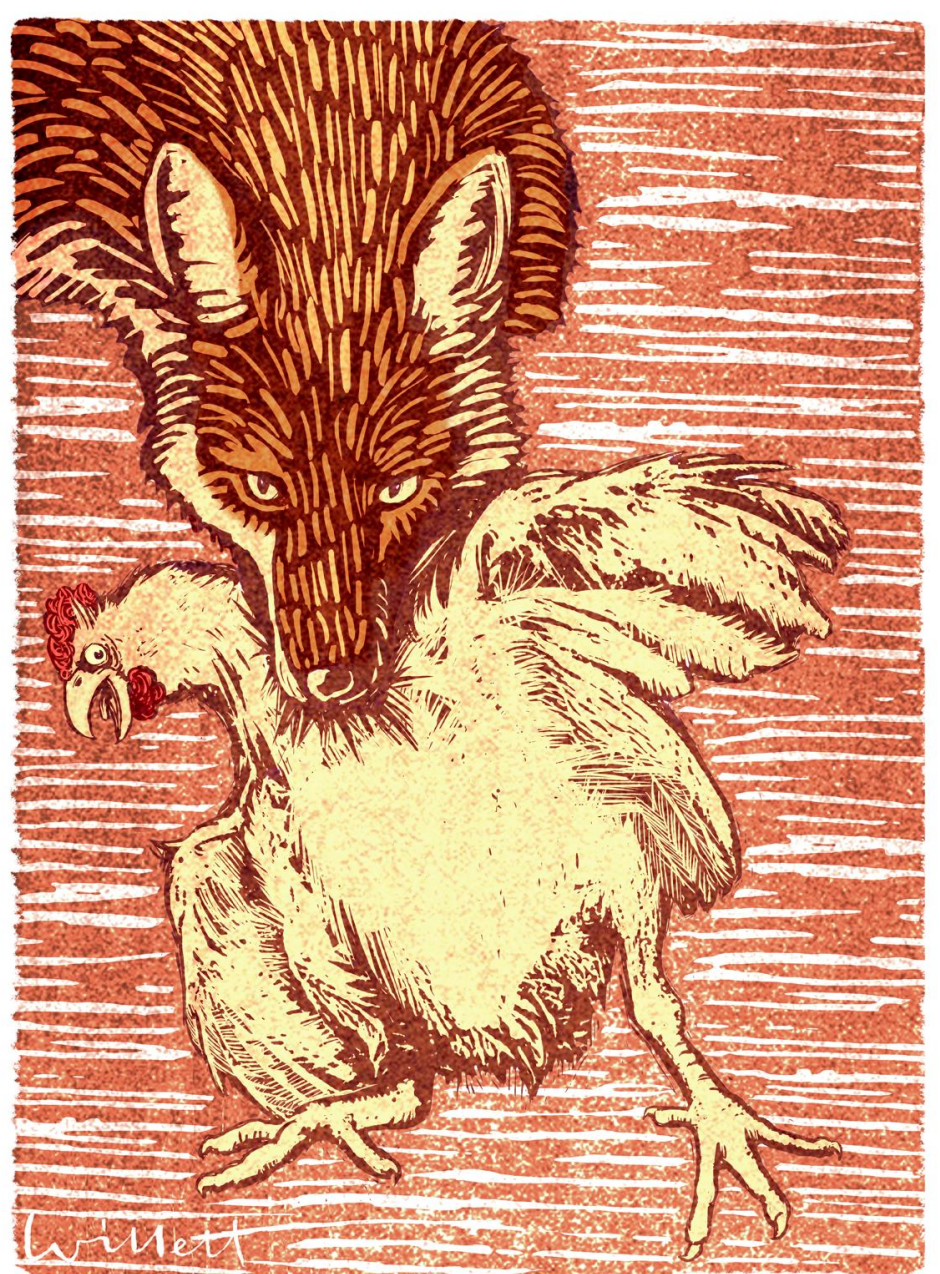

